8. Inoue, Y., Nakamura, R. Mikoshiba, K. \& Tsukada, Y. Brain Res. 219, 85-94 (1981)

9. Sharkey, R. G., Beneski, D. \& Catterall, W. A. Biochemistry 23, 6078-6086 (1984)

10. Schmidt, J., Rossie, S. \& Catterall, W. A. Proc. natn. Acad. Sci. U.S.A. 82, 4847-4851 (1985).

11. Stumer, W., Methfessel, C., Sakman, B., Noda, M. \& Numa, S. Eur. Biophys. J. 14, 131-138 (1987).

12. Sontheimer, H., Trotter, J., Schachner, M. \& Kettenman, H. Neuron 2, 1135-1145 (1989).

13. Barres, B. A., Chun, L. L. Y. \& Corey, D. P. Neuron 2, 1375-1388 (1989).

14. Sheedlo, H. J. \& Siegel, G. J. Brain Res. 415, 105-114 (1987)

15. Waxman, S. G. Black, J. A., Duncan, I. D. \& Ransom, B. R. J. Neurocytol. 19, 11-27 (1990)

16. Waxman, S. G., Black, J. A., Kocsis, J. D. \& Ritchie, J. M. Proc natn. Acad. Sci. U.S.A. 86, 1406-1410 (1989).

17. Scheinman, R. I. et al. J. biol. Chem. 264, 1060-1066 (1989)

18. Chiu, S. Y. \& Schwarz, W. J. Physiol, 391, 631-649 (1987)

19. Caroni, P. \& Schwab, M. E. J. Cell. Biol. 106, 1281-1288 (1988)

20. Hodgkin, A. L. Phil, Trans. R. Soc. Lond. B 270, 297-300 (1975)

21. Campagnoni, A. T. J. Neurochem. 51, 1-14 (1988).

22. Lemke, G. Neuron 1, 535-543 (1988).

23. Sorg. B. J Smith M. M. \& Campagnoni, T I Neurochem 49, 1146-1154 (1987)

24. Frail, D. E. \& Braun, P. E. J. Neurochem. 45, 1071-1075 (1985)

25. Wisniewski, H. M., Oppenheimer, D. \& McDonald, W. E. J. Neuropathol. exp. Neurol. 35, 327 (1976).

26. Smith. K. J. \& McDonald, W. I. Nature 286, 154-155 (1980).

27. Offard, J. \& Catterall, W. A. Neuron 2, 1447-1452 (1989).

28. Lidow, M. S., Goldman-Rakic, P. S., Rakic. P. \& Gallagher. D. W. Brain Res, 459, 105-119 (1988).

29. Bird, T. D., Farrell, D. F. \& Sumo, S. M. J. Neurochem. 31, 387-391 (1978).

30. Mourre, C., Moll, C., Loubet, A. \& Lazdunski, M. Brain Res. 448, 128-139 (1988).

ACKNOWLEDGEMENTS. We thank H. D. Shine for electron microscopy of shiverer optic nerve. This work was supported by March of Dimes/Birth Defects Foundation, NICHD. Blue Bird Circle Foundation for Pediatric Neurology, and a Pew Biomedical Scholars Award (J.L.N.).

\section{Prevention of HIV-1 IIIB infection in chimpanzees by CD4 immunoadhesin}

\author{
Rebecca H. R. Ward, Daniel J. Capon*, \\ Catherine M. Jett†, Krishna K. Murthy†, \\ Joyce Mordenti, Catherine Lucas, Steve W. Frie, \\ Alfred M. Prince $\neq$, James D. Green \\ \& Jorg W. Eichberg $† \S$
}

Genentech Inc., 460 Pt San Bruno Boulevard, S. San Francisco, California 94080 , USA

* Cell Genesys inc., 344 Lakeside Drive, Foster City.

California 94404, USA

† Southwest Foundation for Biomedical Research, San Antonio,

Texas 78284, USA

$\ddagger$ The Lindsley F. Kimball Research Institute of the NY Blood Center, 310 East 67 th Street, New York 10021, USA

$\S$ Present address: Wyeth-Ayerst Research, 145 King of Prussia Road, Philadelphia, Pennsylvania 19087, USA

THE first step in infection by the human immunodeficiency virus (HIV) is the specific binding of gp120, the envelope glycoprotein of HIV, to its cellular receptor, CD4 (see ref. 1 for review). To inhibit this interaction, soluble CD4 analogues that compete for gp120 binding and block HIV infection in vitro have been developed $^{2-8}$. To determine whether these analogues can protect an uninfected individual from challenge with HIV, we used the chimpanzee model system of cell-free HIV infection. Chimpanzees are readily infected with the IIIB strain of HIV-1, becoming viraemic within about 4-6 weeks of challenge, although they do not develop the profound $\mathrm{CD4}^{+}$T-cell depletion and immunodeficiency characteristic of HIV infection in humans ${ }^{9}$. CD4 immunoadhesin (CD4-IgG), a chimaeric molecule consisting of the $\mathrm{N}$-terminal two immunoglobulin-like regions of $\mathrm{CD} 4$ joined to the Fc region of human IgG1 (refs 8, 10), was selected as the CD4 analogue for testing because it has a longer half-life than CD4, contributed by the IgG Fc portion of the molecule. In humans, this difference results in a 25 -fold increased concentration of CD4-IgG in the blood compared with recombinant CD4 (ref. 11). Here we report that pretreatment with CD4-IgG can prevent the infection of chimpanzees with HIV-1. The need for a preventative agent is particularly acute in perinatal HIV transmission. As recombinant CD4-IgG, like the parent IgG molecule, efficiently crosses the primate placenta ${ }^{10}$, it may be possible to set up an immune state in a fetus before HIV transfer occurs, thus preventing infection.

Two chimpanzees were pretreated with CD4-IgG $\left(5 \mathrm{mg} \mathrm{kg}^{-1}\right.$ given intravenously (i.v.)) at $8 \mathrm{~h}$ and $1 \mathrm{~h}$ before challenge, then inoculated with 120 tissue culture infectious doses $\left(\right.$ TCID $\left._{50} \mathrm{~s}\right)$ of HIV-1 IIIB ( 30 chimp infectious doses). After challenge, the animals received further CD4-IgG treatment for 9 weeks. A control animal was similarly challenged but not treated. This dose of HIV-1 IIIB is expected to result in seroconversion of all untreated animals within 9 weeks (see, for example, ref. 12). The serum concentrations of CD4-IgG were predicted from the known human pharmacokinetics and checked by enzyme-linked immunosorbent assay (ELISA) where indicated (Fig. 1). The serum concentrations of CD4-IgG attained during the first 2 days of treatment were estimated to be $50-200 \mu \mathrm{g} \mathrm{ml}^{-1}$, and over the next 5 weeks were predicted to be $5-120 \mu \mathrm{g} \mathrm{ml}^{-1}$; trough concentrations were confirmed by ELISA. When doses were given i.v. (week 6 onwards), the predicted concentrations of $0.5-200 \mu \mathrm{g} \mathrm{ml}^{-1}$ were confirmed by ELISA. Treated animals were also monitored for the development of antibodies to CD4IgG by indirect ELISA. Chimpanzee 37 transiently showed just detectable antibody levels at weeks 7-13 (not shown). Chimpanzee 43 had no detectable antibody response.

Chimpanzees were monitored for HIV infection by detection of virus and by analysis for seroconversion. Virus was detected by a viral coculture assay, in which p 24 production was measured, and by the polymerase chain reaction (PCR). The development of antibodies to HIV proteins was assessed by western blot and ELISA whole-virus based assays. The control animal became infected 3 weeks after challenge, as shown by viral coculture (Table 1), and virus could be detected by PCR at 11 weeks. Antibody to the viral protein p24 became evident in this animal by western blot at week 7 (Fig. 2), and subsequently antibodies to other viral proteins, including gp 120 , were detected. The animal showed seroconversion to HIV by ELISA at week 7 (Table 1). By contrast, the CD4-IgG-treated animals have not shown any signs of infection, after 47 weeks. A single sample from animal 37 (week 23) was positive in two of three PCR assays using a gag primer pair (Table 1), but negative using a pair of env-derived primers of identical sensitivity (Table 1 legend). Further samples from the same animal up to week 47 have repeatedly assayed negative by both PCR and viral culture. It thus seems that both treated animals were protected from infection.

Immunization with recombinant gp120 (ref. 13) or successive immunization with a variety of immunogens including the V3 loop of gp120 (ref. 14) can induce protective immunity in chimpanzees against later challenge with HIV-1 IIIB. But passive protection from HIV infection has not been previously shown. Protection of chimpanzees against HIV-1 by pretreatment with a single high dose of purified hyperimmune gammaglobulin (HIVIG) obtained from AIDS patients has been observed (A.M.P. et al., manuscript in preparation). The control animal described here was shared with the HIVIG study. In our study, treatment with CD4-IgG continued for 9 weeks, in contrast to the single dose of HIVIG. Further work is needed to determine the necessary dose and length of treatment with CD4-IgG.

Azidothymidine (AZT), the only drug currently approved for the treatment of AIDS, has not yet been shown to prevent infection by HIV or simian immunodeficiency virus (SIV) in animal models, whether given before ${ }^{15}$ or after $^{16}$ virus challenge, although it does delay the spread of infection. It is unclear whether AZT can prevent infection after accidental challenge with HIV or maternal-fetal transfer in humans; AZT failures in both forms of challenge are known ${ }^{17,18}$. Clinical trials to address these issues are under way.

Although our results, and those of others (A.M.P. et al., manuscript in preparation), show that it is possible to prevent HIV-1 infection by passive transfer of immunity, it is unclear 
TABLE 1 Detection of HIV infection

\begin{tabular}{|c|c|c|c|c|c|c|c|c|c|}
\hline \multirow[b]{2}{*}{ Week } & \multicolumn{3}{|c|}{ Animal 62 (control) } & \multicolumn{3}{|c|}{ Animal 37 (CD4-lgG) } & \multicolumn{3}{|c|}{ Animal 43 (CD4-igG) } \\
\hline & ELISA & p24 & PCR & ELISA & p24 & PCR & ELISA & p24 & PCR \\
\hline 0 & $<400$ & - & ND & $<400$ & - & ND & $<400$ & - & ND \\
\hline 1 & $<400$ & - & - & $<400$ & - & - & $<400$ & - & - \\
\hline 3 & $<400$ & + & - & $<400$ & - & - & $<400$ & - & - \\
\hline 5 & $<400$ & + & ND & $<400$ & - & ND & $<400$ & - & ND \\
\hline 7 & 400 & + & ND & $<400$ & - & - & $<400$ & - & - \\
\hline 15 & 6400 & + & + & $<400$ & - & - & $<400$ & - & - \\
\hline 19 & 12800 & + & + & $<400$ & - & - & $<400$ & - & - \\
\hline 23 & 12800 & + & + & $<400$ & - & $+1-$ & $<400$ & - & - \\
\hline 27 & 12800 & + & + & $<400$ & - & - & $<400$ & - & - \\
\hline 31 & 12800 & + & + & $<400$ & - & - & $<400$ & - & - \\
\hline 35 & $>6400$ & + & + & $<400$ & - & - & $<400$ & - & - \\
\hline
\end{tabular}

Detection of HIV infection by antibody ELISA and viral culture. Antibody titres against HIV-1 (first column) were determined using a commercial liquid-phase ELISA (Genetics Systems). Cocultivation of HIV was done as described ${ }^{22}$ for 4 weeks and infection was detected by assaying for viral p24 antigen (second column). For PCR analysis (third column), DNA was extracted from peripheral blood mononuclear cells using digestion buffer (10 mM Tris-HCl, pH 8.3, $2.5 \mathrm{mM} \mathrm{MgCl}_{2}, 1 \%$ Tween-20,1\% Nonidet P-40 and $120 \mu \mathrm{g} \mathrm{ml}^{-1}$ proteinase $\mathrm{K}$ ). Lysate was incubated at $60^{\circ} \mathrm{C}$ for $1 \mathrm{~h}$ and extracted with phenol and chloroform. The resulting DNA was solubilized in $25 \mathrm{mM}$ Tris-HCl, pH 7.5. PCR was done essentially as described by Saiki et al. ${ }^{23}$ for $35 \mathrm{cycles}$, using the SK 38/39 primer pair, which is specific for the nucleotide sequence of the p24 core protein. Ten copies of proviral DNA can be detected in this assay, based on titration using the Perkin-Elmer HIV-1 PCR kit. Liquid hybridization was done to detect positive samples. Amplified sample (10 $\mu$ l) was incubated with $1.25 \mathrm{ng}{ }^{32} \mathrm{P}$-labelied SK19 probe (specific activity $10^{7} \mu \mathrm{g}^{-1}$ ) and $1.25 \mu \mathrm{l}$ ReACT buffer at $95^{\circ} \mathrm{C}$ for 10 min and snap-cooled. The tubes were incubated at $56^{\circ} \mathrm{C}$ for $30 \mathrm{~min}$ and centrifuged briefly, loading buffer was added and the samples were applied to a $12 \%$ polyacrylamide gel. Positive samples were detected by autoradiography. The sample from animal 37 (week 23) was also subjected to PCR analysis using primer pairs SK68/69, detected by hybridization with probe SK70, with negative results. DNA (1-3 $\mu \mathrm{g})$ in $1.5 \mathrm{mM} \mathrm{MgCl}_{2}, 10 \mathrm{mM}$ Tris- $\mathrm{HCl}, \mathrm{pH} 8.3,50 \mathrm{mM} \mathrm{KCl}, 0.032 \mathrm{mM}$ each dNTP, $50 \mathrm{ng}$ each primer and 1 unit Taq polymerase was amplified 40 times in a cycle consisting of $94^{\circ} \mathrm{C}, 1 \mathrm{~min} ; 56^{\circ} \mathrm{C}, 1 \mathrm{~min} ; 72{ }^{\circ} \mathrm{C}, 1.5 \mathrm{~min}$. The sensitivity of this PCR reaction is identical to that of the SK38/39 pair described above (10 copies).

ND, not determined.

whether CD4-IgG itself will be clinically effective in this mode. It will be important to test the ability of CD4-IgG to protect against HIV-1 infection using different strains of HIV-1, as some primary patient isolates of HIV-1 are considerably less sensitive than HIV-1 IIIB to inhibition by CD4 derivatives ${ }^{19}$. Also, the challenge was given as cell-free virus; cell-associated virus may be more difficult to inhibit. Nevertheless, these results offer hope for the use of CD4-IgG in the prevention of HIV infection in unborn infants. Currently $15-45 \%$ of the infants born to HIVinfected women are themselves infected (see, for example, ref. 22 ), and no drug is known to decrease transmission. Although there is as yet no definitive information on the time at which
FIG. 1 Predicted blood concentrations of CD4-IgG over the course of treatment. CD4-IgG ( $5 \mathrm{mg}$ per $\mathrm{kg}$ bodyweight) was given i.v. for the first three doses $(-8,-1$ and $+24 \mathrm{~h}$ postchallenge). For the following 5 weeks, daily injections of $2.5 \mathrm{mg} \mathrm{kg}^{-1} \mathrm{CD} 4$-IgG were given intramuscularly (i.m.). On days when the animals were anaesthetized for blood sampling (days 7,14 and 21 ), a $5 \mathrm{mg} \mathrm{kg}^{-1}$ dose was given i.v. (*); on day 35 a $2.5 \mathrm{mg} \mathrm{kg}^{-1}$ dose was given i.v. In weeks $6-9$, an i.v. dose of $6 \mathrm{mg} \mathrm{kg}^{-1}$ was given once per week to reduce the stress on the animals. Weights for chimpanzees 37 and 43 were 63 and $43 \mathrm{~kg}$, respectively. The concentration of CD4-IgG was estimated by assuming that chimpanzee pharmacokinetics closely mimic those observed in humans ( $T$. Hodges, J. D. Allan, J. Kahn and J. Groopman, personal communication), as the body weights are close. For i.v. administration, the CD4-IgG serum concentrations $(C)$ were predicted by dose-adjusting the pharmacokinetics observed in humans following $1 \mathrm{mg} \mathrm{kg}^{-1}$ i.v. bolus injection, which are given by $C\left(\mu \mathrm{g} \mathrm{ml}^{-1}\right)=17.5 \mathrm{e}^{(-0.059 t)}+3.1 \mathrm{e}^{(-0.014 t)}$, where time $(t)$ is in hours, using a multiple dose simulation routine ${ }^{21}$. For i.m. administration, a 9 -h adsorption half-life and $25 \%$ bioavailability were assumed. Squares and circles show serum concentrations of CD4-IgG in chimpanzees 43 and 37, respectively, as measured in a double-sandwich ELISA using two monoclonal antibodies to the CD4 portion of the molecule. The first antibody was passively adsorbed into 96-well microtitre plates in $\mathrm{NaHCO}_{3}$ buffer $(0.05 \mathrm{M})$, pH 9.6, overnight at $4{ }^{\circ} \mathrm{C}$. After washing 3 times with PBS containing $0.05 \%$ Tween-20 (wash buffer), the antibody was blocked with PBS containing 0.5\% BSA and 0.05\% Tween

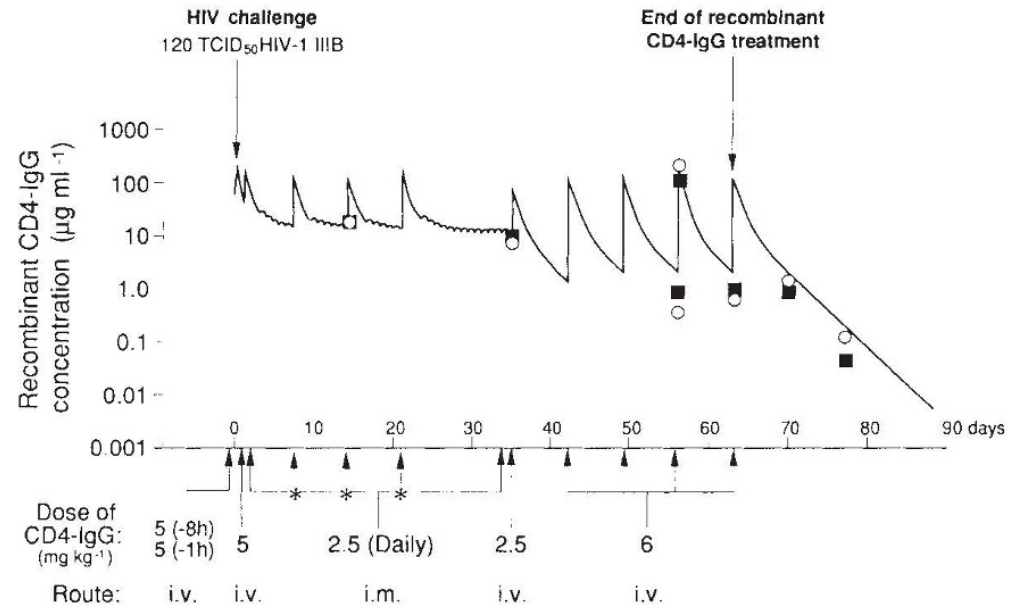

20 for $1 \mathrm{~h}$ at room temperature and washed again. Standards, controls and samples diluted in primate serum diluent were added for $2 \mathrm{~h}$ at room temperature. After washing 3 times in wash buffer, the second antibody, conjugated to horseradish peroxidase, was added for $1 \mathrm{~h}$ at room temperature. Orthophenylene diamine was used as a substrate and plates were read by absorbance at $492 \mathrm{~nm}$ after $\sim 30 \mathrm{~min}$. 
62

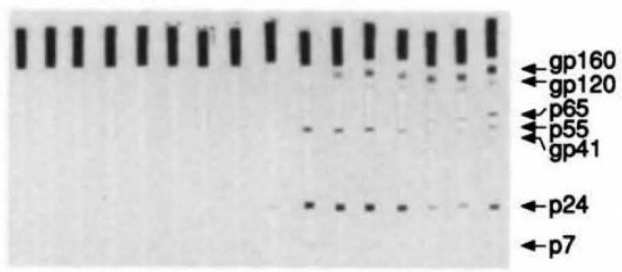

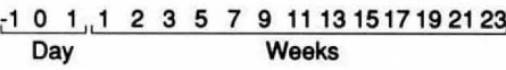

37

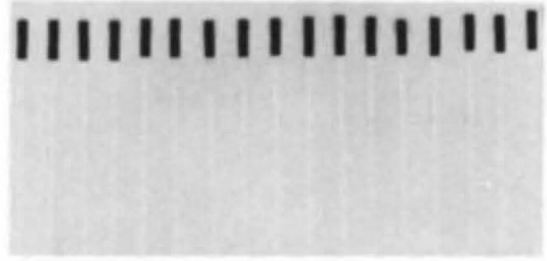

43

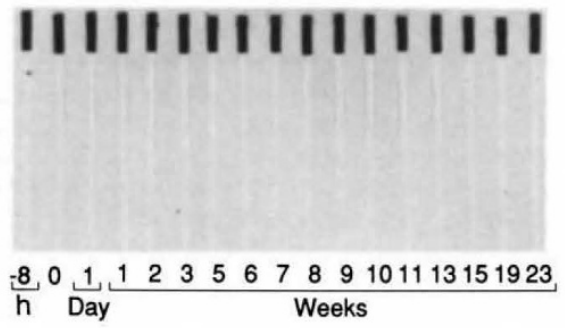

FIG. 2 Western blot seroanalysis of treated (numbers 37 and 43) and control (no. 62) chimps. Samples of serum taken at different times during the protocol were diluted and incubated with commercial (Bio-Rad) western blot strips. The strips were incubated with alkaline phosphate-coupled antihuman IgG (Cappel) and developed using a phosphatase substrate system (Kirkegaard and Perry Laboratories) under conditions recommended by the manufacturers. Samples up to week 47 post-challenge gave identical results (not shown).

fetal infection occurs, an analogy with hepatitis B infection would suggest that most infection occurs late in the third trimester of pregnancy or around the time of delivery. CD4-IgG, like the parent $\mathrm{IgG}$ molecule, is transported across the placental barrier during pregnancy in a rhesus monkey model ${ }^{9}$. Thus it may be possible to provide a protective level of CD4-IgG in the fetus before infection with HIV occurs.

Received 27 February; accepted 10 June 1991.

1. Capon, D. \& Ward, R. H. R. A. Rev. Immun. 9, 649-678 (1991).

2. Smith, D. H. et al. Science 328, 1704-1707 (1987)

3. Fisher, R. et al. Nature 331, 76-78 (1988).

4. Hussey. R. et al Nature $331,78-81(1988)$

5. Deen, K. et al. Nature 331, 82-84 (1988).

6. Traunecker, A., Luke, W. \& Karjalainen, K. Nature 331, 84-86 (1988).

7. Berger, E., Fuerst, T. \& Moss, B. Proc. natn. Acad. Sci. U.S. A. 85, 2357-2361 (1988)

8. Capon, D. et al. Nature 337, 525-531 (1989).

9. Eichberg, J. W. in Animal Models in AIDS (eds Schellekens, H. \& Horzinek, M. C.) 47-52 (Elsevier, Amsterdam, 1990)

10. Byrn, R. et al. Nature 344, 667-670 (1990).

11. Mordenti, J., Chen, S. A., Moore, J. A., Ferraiolo, B. \& Green, J. D. Pharmac. Res. (in the press).

12. Hu, S.-L. et al. Nature 328, $721-723$ (1987).

13. Berman, P. W. et al. Nature 345, 622-625 (1990)

14. Girard, M. et at. Proc. natn. Acad. Sci. U.S.A. 88, 542-546 (1991).

15. McCune, J. M., Namikawa, R., Shih, C. C., Rabin, L. \& Kaneshima, H. Science 247, 564-566 (1990).

16. Marrin, L. N., Murphey-Corb, M., Soike, K. F. \& Davidson-Fairburn, B. 8th A. Symp. Nonhuman Primate Models for AIDS 56 (Delta Regional Primate Research Center, Tulane University, 1990). 17. Lange, I. M. A. et al. New Engl. J. Med. 322, 1375-1377 (1990).

18. Bernard, N. et at. New Engt. J. Med. 323, 916 (1990).

19. Daar, E. S., Li, X. L., Moudgli, T. \& Ho, D. D. Proc. natr. Acad. Sci. U.S.A. 87, 6574-6578 (1990), 20. Blanche, S. et al. New Engl. J. Med. 320, 1643-1648 (1989)

21. Thompson, G. \& Shumaker, R. Drug Metabolism Rev. 21, 463-469 (1989).

22. Anderson, K. P. et al. J. Infect. Dis. 160, 960-969 (1989).

23. Saiki, R. K. et al. Science 230, 487-491 (1985).

ACKNOWLEDGEMENTS. We thank P. Berman, T. Gregory and A. Ammann for heipful discussions, the Process Sciences Department of Genentech inc., for providing purified material, Michelle Sanda and the Assay Services Department, Genentech Inc., for assay support, E. K. Cobb. S. R. Rouse and G. I. Melendez for technical assistance and Carol Morita for assistance with figures. This study was supported in part by the NHLBI.

\section{Prevention of HIV-2 and SIV infection by passive immunization in cynomolgus monkeys}

\author{
Per Putkonen, Rigmor Thorstensson, \\ Lili Ghavamzadeh, Jan Albert*, Kerstin Hild, \\ Gunnel Biberfeld \& Erling Norrby $\dagger$
}

Department of Immunology and * Department of Virology,

National Bacteriological Laboratory, S-10521 Stockholm, Sweden

$\dagger$ Department of Virology, Karolinska Institute,

S-10521 Stockholm, Sweden

INFECTION of macaques with simian immunodeficiency virus (SIV) $^{1,2}$ and human immunodeficiency virus type 2 (HIV-2) ${ }^{3,4}$ are useful models for studies of immunotherapy and vaccination against HIV as well as for testing of antiviral drugs. Vaccine research showing protective immunity in immunized monkeys ${ }^{4-10}$ has indicated that it will be possible to develop a vaccine for prevention of human HIV infection, although many hurdles remain. The design of an HIV vaccine would be helped if the basis of the protective immunity could be elucidated. Passive immune prophylaxis offers a means to determine the relative role of antibodies in protection against infection. We have studied whether a transfer of antibodies can prevent HIV-2 and SIV $_{\text {sm }}$ (SIV of sooty mangabey origin) infection in cynomolgus monkeys. Sera with high antibody titres were collected, heat-treated and injected into naive animals $6 \mathrm{~h}$ before challenge with 10-100 monkey-infectious doses of live homologous virus. All control animals treated with normal monkey serum $(n=6)$ or no serum $(n=39)$ became infected by the challenge virus, whereas five out of seven animals pretreated with antibody-containing serum at a dose of $9 \mathrm{ml} \mathrm{kg}^{-1}$ resisted infection. Thus passively transferred antibodies can protect against a low-dose lentivirus challenge in a nonhuman primate.

Two anti-HIV-2 serum pools were obtained from a cynomolgus monkey (A5) (Macaca fascicularis) which earlier had been immunized with an inactivated whole-virus vaccine and protected against a homologous HIV-2 challenge ${ }^{4}$. This monkey (A5) received five intramuscular $100 \mu \mathrm{g}$ doses of whole, inactivated HIV-2 SBL-6669 emulsified in incomplete Freund's adjuvant on

TABLE 1 Antibody titres in serum pools used for passive immunization of cynomolgus monkeys

\begin{tabular}{cccc}
\hline & \multicolumn{3}{c}{ Titres of antibodies in: } \\
\cline { 2 - 4 } & Whole & V3 & Neutraliza- \\
& antigen & peptide & tion \\
Sample & ELISA & ELISA & assay \\
Anti-HIV-2 serum pool 1 & 70,000 & 1,100 & 1,280 \\
Anti-HIV-2 serum pool 2 & 270,000 & 4,800 & 2,560 \\
Anti-SIV & sm & & 80000 \\
\hline
\end{tabular}

The serum pools had antibody reactivity to gag-pol- and env-encoded structural proteins as detected by immunoblotting using antigen preparation of HIV-2 ${ }_{\text {SBL-6669 }}$ (data not shown). The antibody content of serum pools and passively immunized animals was determined in whole HIV-2 ${ }_{\text {SBL-6669 }}$ viral lysate ELISA ${ }^{15}$ and in homologous V3 peptide ELISA ${ }^{16}$. The V3 peptide assay was included for antibody determination because a recent study ${ }^{17}$ has demonstrated immunogenic dominating linear sites of HIV-2 ${ }_{\text {SBL-6669 }}$ with capacity to induce neutralizing antibodies and cytotoxic antibodies in this region. The neutralizing antibodies were determined by incubation of twofold dilutions of serum and a stock virus preparation of HIV-2 ${ }_{\text {SBL-6669 }}$ or SIV sm $_{\text {sm }}$ before addition of HUT-78 cells. The supernatants were analysed in an HIV-2/SIV antigen assay ${ }^{18}$ after 7 days in culture. The neutralizing titre was defined as the reciprocal of the highest dilution giving a $50 \%$ reduction in absorbance value in the antigen assay. Sera collected from the monkeys before passive immunization were used as negative controls in the serological assays. 